\title{
Teaching Strategies in Online Discussion Board: A Framework in Higher Education
}

\author{
Pao-Nan Chou \\ Department of Education \\ National University of Tainan, Taiwan \\ Tel: 886-6213-3111 ext.974Ｅ-mail:pnchou@mail.nutn.edu.tw
}

Received: February 8, 2012 Accepted: February 11, 2012 Online Published: April 18, 2012

doi:10.5539/hes.v2n2p25

URL: http://dx.doi.org/10.5539/hes.v2n2p25

\begin{abstract}
In order to promote meaningful learning in the online discussion board, this study attempted to identify key factors that affect the online discussion by a literature review and propose an innovative instructional framework to deal with those factors. Through the literature review, five factors were identified. An innovative instructional framework through web 2.0 tools was proposed. One pilot study which applied the framework into the college-level course showed the evidence for supporting student learning. The school educators and instructors in higher education institutions may adopt the cost-effective framework to improve online education.
\end{abstract}

Keywords: Online learning, Online discussion board, Cost-Effective framework

\section{Introduction}

When compared to traditional face-to-face instruction, there is a weakness on the social communication dimension of the online learning environment where online learners can not see other students' facial expressions and convey personal spoken messages to other classmates (Sammons, 2007). Therefore, from the teaching and learning perspectives, promoting social communication between learners by the electronic media plays a crucial role in collaborative online learning.

With advanced technologies available in the market, however, text-based electronic media still dominate social communication in the online courses. Among the text-based electronic media, the online discussion board is the most widely used medium for facilitating learner-learner interaction. In this platform, instructors expect to construct a collaborative learning environment where learners can share their intrinsic learning experiences and negotiate with a common understanding for certain tasks (Moore \& Kearsley, 2005).

To date, a number of studies have explored various factors affecting the effectiveness of the online discussion. However, of those studies, few attempted to categorize the factors and propose related instructional strategies. Therefore, the purpose of this paper was to identify key factors that affect the online discussion by a literature review and propose an innovative instructional framework to deal with those factors.

The framework proposed in this paper bases on the web 2.0 technologies, which are free online software in the market. The school educators and instructors in higher education institutions may adopt this cost-effective framework to improve online education.

\section{Literature Review}

Through the extensive literature review, five key factors were summarized in Table 1.

Detailed description of the above five factors was discussed as follows:

\section{1) Collaborative Learning (Peers Support/ Cooperation/Familiar with Peers/ Social Loafing)}

Peers support plays an important role of promoting complex interaction in asynchronous discussion forums. Fung (2004) found students' level of participation was affected by their peers in an asynchronous discussion forum. He further claimed that when too many peers become lurkers (i.e. lack of participation), students who actively involve in the online discussion will be affected by this phenomenon. Brescia et al. (2004) studied peer teaching in web based threaded discussions. They found that online discussion leaders can support others in discussion activities. The students were able to expand their own knowledge by observing the multiple perspectives presented by other 
peers.

Ling and Ku (2006) found that whether group members had similar or different backgrounds did not seem to have an impact on the degree of learning in an online course. In their research, the group members posted most statements on the group discussion board, initiated most of the interactions between group members, and generated most new ideas through discussions even though they consisted of students from different previous experiences. Thus, the researchers claimed that collaborative learning can help each learner achieve advanced concepts.

In terms of group dynamics, Mabrito (2006) pointed out that learners would like to join the discussion forum and work together with others when they feel more comfortable in an online course. Yang, Newby, and Bill (2005) reported that in the second half of the semester, discussions tended to move toward higher quality of interaction after learners know each other.

Instructors often assign teamwork assignments to online learners during the online discussion. However, Ling and $\mathrm{Ku}$ (2006) found that social loafing was present in group work in the online learning environment. In their study, social loafing happened when one or more participants who did not work as hard or contribute as much as the rest of the group. When the researchers explore what reduced positive attitudes towards online collaborative learning, they found that there were frustrations of not being able to contact each other. Ling and Ku further claimed the difficulty of contacting with other classmates can be a social loafing. Thus, it is an important task for educators to restrict the social loafing phenomenon in order to encourage successful online course.

2) Instructional Strategies (Posting Guidelines/Strategies/ Question type/Argumentation)

Gilbert and Dabbagh (2005) indicated "Guidelines that assisted the facilitation and evaluation of online discussions increased the cognitive quality of student postings promoting a deeper and more meaningful understanding of course content” (p.5).

Pedro (2004) indicated that given the goal of promoting peers as sources of information and knowledge, strategies for getting students to reply to each other's postings must be developed and documented. Pedro (2004) found that the requirement of a summary would be valuable for dynamic arrangement of postings in the asynchronous discussion forums. Yang, Newby, and Bill (2005) explored the effects of using Socratic questioning to enhance students' critical thinking skills in asynchronous discussion forums. The result showed that critical thinking skills and attitudes provided evidence that teaching critical thinking is worth the effort. Fung (2004) pointed out that instructors can utilize social activities to develop critical thinking in the asynchronous discussion forum. Flowers and Cotton (2007) found that the quality of postings was increased when the instructor implemented self-assessment method. Hemphill and Hemphill (2007) indicated through the content analysis of postings, students' critical thinking skills were enhanced by the presence of guest speakers.

Baglione and Nastanski (2007) indicated that if an online teacher designed a question that is too broad or too vague, the question would reduce learners' interest to post their thinking. Similarly, Bradley et al. (2008) found that the question type provided by instructors would yield postings containing different thinking processes.

Oh and Jonassent (2007) found that constraint-based argumentation scaffolding improved learners’ argumentation performance and stimulate reflection process in online discussions. Spatariu et al. (2007) reported that a discussion leader's intervention would improve the quality of argumentation in online discussions.

\section{3) Instructor' role/ Mentor Support}

Educators' interventions in the online discussion have an influence on learners' participation (Kuboni \& Martin, 2004). Lu and Jeng (2006) contented that instructors should take a role of facilitator in the online discussion where learners' knowledge construction was guided by instructors. In Mabrito's (2006) study, the findings showed that course mentors' encouragement was helpful for student learning in the online courses. Knowlton (2003) mentioned that if educators directed learners to construct knowledge actively through communication with tutors, learners would be more likely to join the online threaded discussions. Fung (2004) pointed out that instructors' scaffolding played an important role for learners’ online discussions.

\section{4) Communication (Interaction/Technical Errors/ Social Presence)}

Ling and $\mathrm{Ku}$ (2006) utilized the content analysis of messages of the asynchronous group discussion board to measure degree of participation and suggested that the instructor should incorporate communication, cooperation, compromise, complement, and commitment within the course setting. These factors enable each group members to have better working relationships with each other and hence develop effective communication.

Technical errors on communication also provoke a challenge for online learners. By the qualitative analysis of learners' opinions, Tu and McIsaac (2002) found that keyboarding skills would influence students' efficiency in 
online discussions. Also, typographical errors often caused misunderstandings among learners.

Lack of verbal cues in the online environment, social presence played an important role in online discussions. Tu (2001) reported that the social presence affected learners' perceptions of online communication.

\section{5) Course Guideline/Resources}

Educators should realize that not every student had taken an online course before. Learners' prior experiences have a positive influence in an asynchronous discussion forum. Mandernach, Amber, and Emily (2007) found that if learners have no or few prior experiences of taking online courses, the lack of postings would happen in an online session.

Johnson (2007) explored students' perceptions of online learning in the asynchronous discussion board and reported that the instructor must build a framework around the notion of the online discussion and help learners to access the course materials. Kuboni and Martin (2004) analyzed learners' participation in a distance education program and found that most of participators perceived a course guide as a useful resource after they receive it. Fung (2004) indicated that if learners could easily utilize course resources, they would participate more enthusiastically in a collaborative online discussion.

\section{Research Method}

This study adopted an action research design. According to Gall et al. (2007), the purpose of action research is to "increase the quality, impact, and justice of education professionals' practice" (p. 597). The rationale for using the action research design is that the study attempted to propose a feasible framework to deal with instructional problems that many instructors face in the online discussion. In such way, it is expected that the results of this study may offer an instructional solution for education professionals at higher education institutions who seek to improve the quality of online discussions.

Three research processes guide this study. First, the extensive literature review identifies five factors that may affect the online discussion. Second, a proposed instructional framework responds the five factors. Third, a pilot study which applied the framework into a college-level course was discussed.

\section{Discussion: A Cost-Effective Framework}

In respond to five factors discussed earlier, a cost-effective instructional framework to promote online asynchronous discussions was proposed. The strategy, which makes full use of web 2.0 tools (free tools), was summarized as the follows:

\section{1) Blogging (related to factor 1 and factor 2)}

Past research has showed reflection can trigger intellectual growth (Chou, 2007). Course instructors can encourage online learners to make weekly entry in their personalized blogs. A blog entry may contain their weekly reflection on course contents. Moreover, from a collaborative learning perspective, learners can give comments on reflection entries.

2) Skype (related to factor 3 and factor 4)

Skype allows more than 24 people to chat at the same time. Course instructors can schedule a time to engage in a real-time discussion. Verbal discussions can avoid misunderstandings caused by the text-discussion. Moreover, like office hour in the face-to-face environment, a weekly discussion created by course instructors can guide online learners into a right track.

3) Podcasting (related to factor 5)

In the text-based environment, course instructors need to develop some video and audio materials to support student learning. The function of Multimedia could facilitate the learning effectiveness of the text-reading.

4) Facebook (related to factor 1)

Familiar with each other will be beneficial to collaborative learning. Instructors can encourage online learners to engage in social networking. In the Facebook platform, each learner can understand much more about peers' backgrounds.

5) Wiki (related to factor 1 and factor 2)

Course instructors can set up a wiki platform so that students can contribute their efforts on team projects. The benefit of the wiki platform is that course instructors can observe what learners did during project development.

Table 2 summarizes the above discussion results. 


\section{Implementation of the Framework: A Pilot Study}

In order to test the feasibility of the proposed framework, a pilot study was implemented in a college-level course. Details are:

1) Course Scenario

The course entitled "Media Literacy Education" was offered in the department of education at a southern Taiwan university. The course instructor established an online discussion board in an e-learning system. Students who enrolled in the course should participate in an after-class online discussion to fulfill the course requirement.

2) Instructional Strategy1: Facebook

The instructor asked students to register the Facebook accounts. When logging into the Facebook platform, students could obtain classmates' information about recent daily activities. The informal interaction in the Facebook might strengthen students' familiarity with other peers.

3) Instructional Strategy2: Podcasting

The instructor employed a podcasting website (podomatic) to record several instructional resources, such as course guidelines and requirements. Once students could not understand the rules of the online discussion, they might seek for verbal instruction (podcasting contents) from the instructor.

4) Instructional Strategy3: Skype

The instructor used the Skype to set up an online office hour. Instead of text-communication, students could chat with the instructor to discuss course-related issues. Also, the instructor invited several students to express their "oral" opinions via the Skype.

5) Instructional Strategy4: Blogging

The instructor asked students to reflect their online discussions by writing online journals (Google Blog). Each week, students should engage in a reflective learning regarding their performances in the online discussion board.

6) Instructional Strategy5: Wiki

Traditionally, the online discussion is an individual task. In other words, the responsibility for students is to write postings. In order to enhance the concept of the team-work, the instructor segregated students into different groups. Each group used a wiki page (PB wiki website) to organize important ideas and then wrote postings (results) in the discussion board.

7) Evaluation

After completing the online discussion in the last week of the class, students were asked to express their opinions about the instructional strategies. A 5-point Likert-scale questionnaire surveyed students' attitudes about web 2.0 technologies. Table 3 shows the evaluation results. Overall, students were satisfied with the adoption of web 2.0 technologies in online discussions.

\section{Conclusion}

In this study, five key factors that may affect the online discussion were identified and a cost-effective instructional framework that can improve online discussion outcome was proposed. In order to achieve a meaningful online discussion, instructors must be aware of these factors and can employ the framework to manage the online discussion board, thereby supporting a successful online collaborative learning.

Even though the initial finding of the pilot study shows that the proposed framework can support student learning in the online discussion board, future research need to apply the instructional strategies into different learning domains (i.e. engineering education). Various learning subjects in online discussions may yield unexpected outcomes.

\section{References}

Baglione, S. L., \& Nastanski, M. (2007). The Superiority of online discussion faculty perceptions. The Quarterly Review of Distance Education, 8(2), 139-150.

Bradley M. E., Thom, L. R., Hayes, J., \& Hay, C. (2008). Ask and you will receive: How question type influences quantity and quality of online discussions. British Journal of Educational Technology, 39(5), 888-900. http://dx.doi.org/10.1111/j.1467-8535.2007.00804.x

Brescia, W. F. et al. (2004). Peer Teaching in web based threaded discussions. Journal of Interactive Online 
Learning, 3(2), Online Edition.

Chou, P.-C. (2007). A literature review on instructional systems design, portfolio, and e-portfolio. Unpublished Master Paper. The Pennsylvania University, University Park.

Flowers, J, \& Cotton, S. E. (2007). Impacts of student categorization of their online discussion contributions. The American Journal of Distance Education, 21(2), 93-104. http://dx.doi.org/10.1080/08923640701299058

Fung, Y. H. (2004). Collaborative online learning: interaction patterns and limiting factors. Open Learning, 19(2), 135-149. http://dx.doi.org/10.1080/0268051042000224743

Gall, M.D., Gall, J. P., \& Borg, W. R. (2007). Educational Research: An introduction (8 ${ }^{\text {th }}$ edition). Boston: Pearson/Allyn \& Bacon.

Gilbert, P., \& Dabbagh, Y. (2005). How to structure online discussions for meaningful discourse: a case study. British Journal of Educational Technology, 36(1), 5-12. http://dx.doi.org/10.1111/j.1467-8535.2005.00434.x

Hemphill, L. S., \& Hemphill, H. H. (2007). Evaluating the impact of guest speaker postings in online discussions. British Journal of Educational Technology, 38 (2), 287-293. http://dx.doi.org/10.1111/j.1467-8535.2006.00622.x

Johnson, H. (2007). Dialogue and the construction of knowledge in e-learning: Exploring students' perceptions of their learning while using blackboard's asynchronous discussion board. European Journal of Open and Distance Learning, 1, Online Edition.

Knowlton, D. S. (2003). Evaluating college students' efforts in asynchronous discussion. The Quarterly Review of Distance Education, 4(1), 31-41.

Kuboni, O., \& Martin, A. (2004). An assessment of support strategies used to facilitate distance students' participation in a web-based learning environment in the university of the west Indies. Distance Education, 25(1), 7-29. http://dx.doi.org/10.1080/0158791042000212431

Ling, T., \& Ku, H.Y. (2006). A case study of online collaborative learning. The Quarterly Review of Distance Education, 7(4), 361-375.

Lu, L.-F, \& Jeng, I. (2006). Knowledge construction in inservice teacher online discourse: Impacts of instructor roles and facilitative strategies. Journal of Research on Technology in Education, 39(2), 183-202.

Mabrito, M. (2006). A study of synchronous versus asynchronous collaboration in an online business writing class. The American Journal of Distance Education, 20(2), 93-107. http://dx.doi.org/10.1207/s15389286ajde2002_4

Mandernach, B. J., \& Amber, D. H., \& Emily, D. S. (2007). Frequency and time investment of instructors' participation in threaded discussions in the online classroom. Journal of Interactive Online Learning, 6(1), 1-8.

Moore, M., \& Kearsley, G. (2005). Distance education: A systems view (2 $2^{\text {nd }}$ edition). Belmont, CA: Thomson Wadsworth.

Oh, S., \& Jonassent (2007). Scaffolding online argumentation during problem solving. Journal of Computer Assisted Learning, 23, 95-110. http://dx.doi.org/10.1111/j.1365-2729.2006.00206.x

Pedro, H. R. (2004). Web Logs and online discussions as tools to promote reflective practice. Journal of Interactive Online Learning, 3(1), 1-12.

Sammons, M. (2007). Collaborative interaction. In M. G. Moore. Handbook of distance education ( $2^{\text {nd }}$ edition)(pp. 311-321). Mahwah, NJ: Lawrence Erlabaum Associates.

Spatariu, A. et al. (2007). The influence of the discussion leader procedure on the quality of arguments in online discussion. Journal of Educational Computing Research, 37(1), 83-103. http://dx.doi.org/10.2190/B580-2R37-P220-65V4

Tu, C. H, \& McIsaac, M. (2002). The relationship of social presence and interaction in online classes. The American Journal of Distance Education, 16(3), 131-150. http://dx.doi.org/10.1207/S15389286AJDE1603_2

Tu, C. H. (2001). How Chinese perceive social presence: An examination of interaction in online learning environment. Education Media International, 38(1), 45-60. http://dx.doi.org/10.1080/09523980010021235

Yang, Y. C., \& Newby, T.J., \& Bill, R. (2005).Using socratic questioning to promote critical thinking skills through asynchronous discussion forums in distance learning environments. The American Journal of Distance Education, 19 (3), 163-181. http://dx.doi.org/10.1207/s15389286ajde1903_4 
Table 1. Five Factors Affecting Online Discussion

\begin{tabular}{|l|l|}
\hline Item & Factors \\
\hline 1 & Collaborative Learning (Peers Support/ Cooperation/Familiar with Peers/ Social Loafing) \\
\hline 2 & Instructional Strategies (Posting Guidelines/Strategies/ Question type/Argumentation) \\
\hline 3 & Instructor' role/ Mentor Support \\
\hline 4 & Communication (Interaction/Technical Errors/ Social Presence) \\
\hline 5 & Course Guideline/Resources \\
\hline
\end{tabular}

Table 2. Framework to Promote Online Asynchronous Discussion

\begin{tabular}{|l|l|}
\hline Strategy & Factors \\
\hline Blogging & Collaborative Learning/ Instructional Strategies \\
\hline Skype & Instructor' role/ Mentor Support/Communication \\
\hline Podcasting & Course Guideline/Resources \\
\hline Facebook & Collaborative Learning \\
\hline Wiki & Collaborative Learning/ Instructional Strategies \\
\hline
\end{tabular}

Table 3. Framework Evaluation $(\mathrm{N}=50)$

\begin{tabular}{|l|l|}
\hline Item* & Mean \\
\hline Blogging & 4 \\
\hline Skype & 4.2 \\
\hline Podcasting & 4.5 \\
\hline Facebook & 4.4 \\
\hline Wiki & 3.8 \\
\hline
\end{tabular}

*Question (How do you perceive those educational tools which support your learning?) 